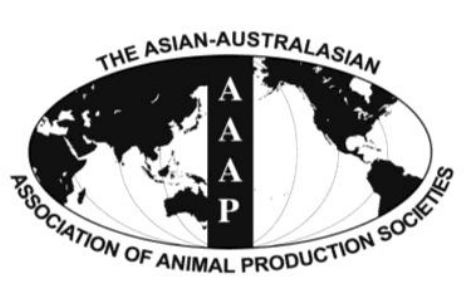

Open Access

Asian Australas. J. Anim. Sci.

Vol. 27, No. 10 : 1469-1477 October 2014

http://dx.doi.org/10.5713/ajas.2014.14190

www.ajas.info

pISSN 1011-2367 elSSN 1976-5517

\title{
Dietary Supplementation of Magnesium Sulfate during Late Gestation and Lactation Affects the Milk Composition and Immunoglobulin Levels in Sows
}

\author{
W. X. Hou, S. Y. Cheng, S. T. Liu, B. M. Shi*, and A. S. Shan* \\ Institute of Animal Nutrition, Northeast Agricultural University, Harbin 150030, China
}

\begin{abstract}
This experiment was conducted to investigate the effects of dietary supplementation of magnesium sulfate $\left(\mathrm{MgSO}_{4}\right)$ during late gestation and lactation on sow and litter performance, fecal moisture, blood biochemistry parameters, immunoglobulin levels and milk composition in sows. Forty-eight sows (Yorkshire $\times$ Landrace, 4th to 5th parity) were randomly allocated to 1 of 4 dietary treatments supplemented with $0,200,400$, or $600 \mathrm{mg} / \mathrm{kg} \mathrm{MgSO}_{4}(\mathrm{n}=12)$. The experiment started on day 90 of gestation and continued through day 21 of lactation. Blood samples were collected on day 107 of gestation, day 0 (farrowing) and 21 (weaning) of lactation for the analyses of the blood biochemistry parameters and immunoglobulin levels. The colostrum and milk samples were obtained on day 0 and 14 of lactation, respectively. Fecal samples were collected from the sows on day 107 of gestation as well as day 7 and 20 of lactation to determine fecal moisture content. The results showed that the survival percentage of piglets and the litter weight at weaning were decreased linearly $(\mathrm{p}<0.05)$ and other parameters of the sow or litter performance were not influenced $(\mathrm{p}>0.05)$ by $\mathrm{MgSO}_{4}$ supplementation. The fecal moisture content of the sows were increased ( $\mathrm{p}<0.05)$ linearly as dietary $\mathrm{MgSO}_{4}$ increased on day 7 and 20 of lactation. Supplementation with $\mathrm{MgSO}_{4}$ increased the plasma magnesium $(\mathrm{Mg})$ level linearly $(\mathrm{p}<0.05)$ and had a trend to increase total protein level $(\mathrm{p}>0.05$ and $\mathrm{p}<0.10)$. However, an increase in the dietary $\mathrm{MgSO}_{4}$ level resulted in a linear decrease in the colostrum fat content $\left(\mathrm{p}<0.05\right.$ ). Dietary $\mathrm{MgSO}_{4}$ supplementation enhanced the immunoglobulin $\mathrm{G}(\mathrm{IgG})$ level (linear, $\mathrm{p}<0.05$ ) in plasma on day of farrowing and immunoglobulin $\mathrm{A}(\operatorname{IgA})$ level in colostrum (quadratic, $\mathrm{p}<0.05)$ and milk (linear, $\mathrm{p}<0.05$ ) of the sows. These results indicated that supplementation with $\mathrm{MgSO}_{4}$ during late gestation and lactation may have the potential to prevent sow constipation, but may also result in some negative effects. (Key Words: Magnesium Sulfate, Sow, Performance, Fecal Moisture, Immunoglobulin, Milk Composition)
\end{abstract}

\section{INTRODUCTION}

Magnesium $(\mathrm{Mg})$ is a macro-mineral that participates in the metabolism of carbohydrates, nucleic acids, proteins and lipids and contributes to the action of many enzymes as well as cellular transport (Trawńska et al., 2013). Magnesium ion is required for the synthesis of ATP and proper functioning of immune system and it mitigates states of supernormal excitability and enhances resistance to stress (Maguire and Cowan, 2002; Wolf and Cittadini, 2003;

* Corresponding Authors: B. M. Shi. Tel: +86-0451-55190685, Fax: +86-0451-55190685, E-mail: shibaoming1974@163.com / A. S. Shan. E-mail: asshan@ @eau.edu.cn Submitted Mar. 11, 2014; Revised May 1, 2014; Accepted Jun. 10, 2014
Guerrera et al., 2009; Siener et al., 2011). Common cornsoybean diets fed to monogastric animals contain adequate amounts of $\mathrm{Mg}$, and deficiencies of $\mathrm{Mg}$ are rare (Lee and Britton, 1980). However, studies have demonstrated that supplementing $\mathrm{Mg}$ to swine diets alleviated the effects of stress and improved meat quality (D'souza et al., 1998; Apple et al., 2005). It has been also confirmed that $\mathrm{MgSO}_{4}$ had the capability of reducing heat stress-induced oxidative damage in broilers (Yang et al., 2012). Moreover, $\mathrm{MgSO}_{4}$ can be used as a laxative in a clinical practice (Ikarashi et al., 2012). It has been demonstrated that dietary $\mathrm{MgSO}_{4}$ supplementation could reduce the number of constipated fininshing pigs and furthermore, the addition of $400 \mathrm{mg} / \mathrm{kg}$ $\mathrm{MgSO}_{4}$ in the finishing pig diet could effectively prevent and control the occurrence of constipation (Tang, 2000).

Copyright $@ 2014$ by Asian-Australasian Journal of Animal Sciences This is an open-access article distributed under the terms of the Creative Commons Attribution Non-Commercial License (http://creativecommons.org/licenses/by-nc/3.0/), which permits unrestricted non-commercial use, distribution, and reproduction in any medium, provided the original work is properly cited. 
Most previous studies have focused on the effects of dietary $\mathrm{MgSO}_{4}$ intake on broilers, cows and growing-finishing pigs, however, fewer experimental studies are available on the effect of $\mathrm{MgSO}_{4}$ supplementation on sows.

With the increase of the intensiveness of sow breeding practices, reproductive barriers occurred, such as constipation (Liu and Luo, 2010). As sows approach farrowing, mild constipation is a common state because the intestine is less active (Tabeling et al., 2003). Feed intake and intestinal activity undergo major changes around farrowing when sows are often constipated (Oliviero et al., 2009). Constipation is associated with udder infections in sows during early lactation (Hermansson et al., 1978; Smith, 1985) and may cause pain or discomfort, as well as affect the duration of farrowing (Cowart, 2007). In commercial production, sow perinatal feed can be top-dressed with $\mathrm{MgSO}_{4}$ at $1.0 \%$ for several days as a treatment for constipation (Shi, 2010). Furthermore, $\mathrm{MgSO}_{4}$ can be included in the fininshing pig diets at $400 \mathrm{mg} / \mathrm{kg}$ as a preventative of constipation (Tang, 2000). It has not yet been investigated whether $\mathrm{MgSO}_{4}$ supplementation of sows influences performance, milk composition and other parameters. Therefore, the aims of this study were to determine whether supplementation of $\mathrm{MgSO}_{4}$ to the sow diets at 200, 400 and $600 \mathrm{mg} / \mathrm{kg}$ during late gestation and lactation could prevent the sow constipation and to investigate the effects of $\mathrm{MgSO}_{4}$ on sow and litter performance, blood biochemistry parameters, immunoglobulin levels and milk composition in sows.

\section{MATERIALS AND METHODS}

The Institutional Animal Care and Use Committee of Northeast Agricultural University (Harbin, China) approved all of the experimental protocols.

\section{Animal, treatment and management}

Forty-eight sows (YorkshirexLandrance, 4th to 5th parity) were artificially inseminated with semen from a pool of Duroc boars. The sows were randomly allocated to 1 of 4 dietary treatments and fed with the basal diet or the basal diet supplemented with 200, 400 or $600 \mathrm{mg} / \mathrm{kg} \mathrm{MgSO}_{4}$. The experiment started on day 90 of gestation and continued through day 21 of lactation. The ingredients and chemical composition of the basal diets for gestating and lactating sows are shown in Table 1. All of the diets were formulated to meet or exceed the sow's nutrient requirements, as recommended by the National Research Council (1998). The magnesium sulfate monohydrate $\left(\mathrm{MgSO}_{4} \cdot \mathrm{H}_{2} \mathrm{O}, \geq 99 \%\right.$; $\mathrm{MgSO}_{4}, \geq 86 \%$; $\mathrm{Mg}, \geq 17.21 \%$ ) used for the experiments was purchased from Harbin Veterinary Medicine Wholesale Market (Harbin, China). During late gestation, twelve sows of each treatment were randomly housed in 3 pens of 4.0
Table 1. Composition of experimental diets (as-fed basis)

\begin{tabular}{lcc}
\hline & Gestation & Lactation \\
\hline Ingredients $(\%)$ & & \\
Maize & 65.07 & 56.25 \\
Wheat bran & 18.00 & 10.00 \\
Full-fat soybean, 35.5\% CP & - & 5.00 \\
Soybean meal, 43\% CP & 13.30 & 21.20 \\
Fish meal & - & 2.00 \\
Soy oil & - & 2.00 \\
Dicalcium phosphate & 1.05 & 1.05 \\
Limestone & 1.08 & 1.00 \\
Salt & 0.40 & 0.40 \\
Choline chloride $(50 \%)$ & 0.10 & 0.10 \\
Vitamin and mineral premix & 1 & 1.00 \\
Chemical composition & 1.00 & \\
Metabolizable energy ${ }^{2}\left(\mathrm{MJ} / \mathrm{kg}^{1}\right)$ & 11.92 & 12.74 \\
Crude protein $^{3}(\%)$ & 13.97 & 18.88 \\
Crude fibre $^{3}(\%)$ & 3.52 & 3.30 \\
Calcium $^{3}(\%)$ & 0.71 & 0.79 \\
Total phosphorus $^{3}(\%)$ & 0.56 & 0.62 \\
Magnesium $^{3}(\%)$ & 0.20 & 0.19 \\
\hline CP, crude protein. & &
\end{tabular}

$\mathrm{CP}$, crude protein.

${ }^{1}$ Supplied per kg of diet: $20 \mathrm{mg}$ of $\mathrm{Cu}$ as $\mathrm{CuSO}_{4} \cdot 5 \mathrm{H}_{2} \mathrm{O} ; 120 \mathrm{mg}$ of $\mathrm{Zn}$ as $\mathrm{ZnSO}_{4} ; 0.3 \mathrm{mg}$ of Se as $\mathrm{Na}_{2} \mathrm{SeO}_{3} \cdot \mathrm{H}_{2} \mathrm{O} ; 40.07 \mathrm{mg}$ of $\mathrm{Mn}$ as $\mathrm{MnSO}_{4} \cdot \mathrm{H}_{2} \mathrm{O}$; $100.50 \mathrm{mg}$ of $\mathrm{Fe}$ as $\mathrm{FeSO}_{4} \cdot \mathrm{H}_{2} \mathrm{O} ; 0.3 \mathrm{mg}$ of $\mathrm{I}$ as $\mathrm{Ca}\left(\mathrm{IO}_{3}\right)_{2}$; vitamin A, 13,500 IU; vitamin $\mathrm{D}_{3}$, 3,000 IU; vitamin $\mathrm{E}, 15 \mathrm{IU}$; vitamin $\mathrm{K}_{3}, 3 \mathrm{mg}$; thiamine, $1.8 \mathrm{mg}$; riboflavin, $6 \mathrm{mg}$; pyridoxine, $0.3 \mathrm{mg}$; vitamin $\mathrm{B}_{12}$, $0.024 \mathrm{mg}$; niacin, $24 \mathrm{mg}$; pantothenic acid, $15 \mathrm{mg}$; folate, $0.9 \mathrm{mg}$; biotin, $0.03 \mathrm{mg}$.

${ }^{2}$ Calculated values.

${ }^{3}$ Analyzed values.

$\mathrm{m} \times 3.0 \mathrm{~m}$ and all gestating sows were in the same room. The sows were fed approximately $3.0 \mathrm{~kg} / \mathrm{d}$ of the gestation diet from day 90 of gestation until the day of farrowing. On day 107 of gestation, the sows were moved to the farrowing room and housed in individual farrowing stalls $(1.5 \mathrm{~m} \times 2.1$ $\mathrm{m})$. On day 0 of lactation, the sows were not fed the lactation diet. The feed allowance of the sows was raised to $2.0 \mathrm{~kg}$ on day 1 . Thereafter, this amount was increased daily by $1.0 \mathrm{~kg}$ until ad libitum feeding. The lactation diet was provided three times daily. The sows and piglets had free access to water from nipple waterer throughout the experiment. The farrowing stalls had a piglet creep area provided with a heat lamp. The average daily feed intake (ADFI) of the sows during lactation was recorded. The sow weight was recorded at entry into the farrowing room and at the time of weaning. The backfat thickness was measured at P2 (6 cm from the midline at the head of the last rib) with an ultrasonic device (Renco Lean Meater Type 7, Minneapolis, MN, USA) within $24 \mathrm{~h}$ after farrowing and on day 21 of lactation. The weaning-to-estrus interval (WEI) of each sow was recorded from weaning to 7 days postweaning. At day 3 postpartum, the piglets received an iron injection, and the males were castrated at day 5 postpartum. 
Commercial creep diets were offered to the piglets at day 7 postpartum. The piglets were not cross-fostered, and they were counted and weighed at birth and weaning.

\section{Sample collection}

Blood, colostrum, milk, and fecal samples were collected from eight sows per experimental treatment. Blood samples $(10 \mathrm{~mL})$ were collected from the ear vein of the sows into heparin tubes on day 107 of gestation as well as day 0 and 21 of lactation for the analyses of blood biochemistry parameters and immunoglobulin levels. The blood samples were centrifuged at $1,000 \times \mathrm{g}$ for $10 \mathrm{~min}$. Then, all of the plasma samples were stored at $-20^{\circ} \mathrm{C}$ until needed for analysis.

Approximately $30 \mathrm{~mL}$ of colostrum was manually collected $1 \mathrm{~h}$ after the birth of the first piglet from all functional glands. Piglets were removed from the sow until completion of farrowing to prevent suckling and the initiation of gut closure. To facilitate milk sampling on day 14 of lactation, piglets were removed from the sow $1 \mathrm{~h}$ before and milk ejection was induced after intramuscular administration of $2 \mathrm{~mL}$ of oxytocin. The colostrum and milk samples were immediately frozen at $-20^{\circ} \mathrm{C}$ until the analysis.

Fresh fecal samples were collected from the sows on day 107 of gestation as well as day 7 and 20 of lactation. The fecal samples were stored at $-20^{\circ} \mathrm{C}$ until analysis. Every morning before the daily cleaning, we observed the faeces of each sow from five days before to five days after farrowing. The sow with dry and pellet-shaped faeces or no faecal production for three or four consecutive days was defined as severe constipation (Oliviero et al., 2009).

\section{Chemical analyses}

Samples of the gestation and lactation diets were analyzed for crude protein $(\mathrm{CP})$, crude fibre $(\mathrm{CF})$, calcium (Ca) and phosphorus (P) (Association of Official Analytical Chemists [AOAC], 2006). Dietary Mg was determined by atomic absorption spectrophotometer (PE AA 800, Waltham Mass, USA). The milk composition was analyzed using a fully automatic milk analyzer (Milko ScanTM FT+ Analyser, Foss, Hillerød, Denmark). The blood biochemistry parameters including plasma $\mathrm{Mg}$, total protein and triglycerides, were measured by a fully automated biochemical analyzer (Unicel DxC 800 Synchron Clinical System, Beckman Coulter, Fullerton, CA, USA). The immunoglobulin concentrations in the plasma, the colostrum and milk were assessed by immune turbidimetry using immunoglobulin-specific kits (Sanwei Biological Engineering Company Limited, Shandong, China). The milk samples were ultracentrifuged at $3,000 \times \mathrm{g}$ at $4{ }^{\circ} \mathrm{C}$ for 30 min to remove the free fat, and the supernatant was separated and kept frozen until the analyses of the immunoglobulin levels. The supernatant samples were analyzed in duplicate at dilution levels of 1:2 for colostrum immunoglobulin $\mathrm{G}$ ( $\mathrm{IgG}), 1: 1$ for colostrum immunoglobulin $\mathrm{A}(\operatorname{Ig} \mathrm{A})$ and 1:1 for colostrum immunoglobulin $\mathrm{M}(\operatorname{IgM})$, respectively. The determination of the immunoglobulins was performed using an ultraviolet spectrophotometer (UV2401PC, Shimadzu Co., Kyoto, Japan). The optical density (OD) values of the standards and samples at $700 \mathrm{~nm}$ (IgG) or $340 \mathrm{~nm}$ (IgA and IgM) were measured. The immunoglobulin concentrations of the samples $(\mathrm{g} / \mathrm{L})$ were calculated by comparing the OD value of the samples to the standard curve. The fecal samples (10 g) were thawed at room temperature and weighed on a dry plate and then weighed again after drying for $24 \mathrm{~h}$ at $65^{\circ} \mathrm{C}$ in a constant temperature drying box to a constant weight. The water content of the feces was calculated based on the difference between the wet and dry fecal weights.

\section{Statistical analysis}

Differences between treatments were examined using a one-way ANOVA (SPSS 17.0, SPSS Inc., Chicago, IL, USA) with individual sows and their litters being the experimental unit. The linear and quadratic effects of $\mathrm{MgSO}_{4}$ level were assessed using orthogonal polynomials. A p-value of less than 0.05 was considered statistically significant and tendency for all analysis was $p>0.05$ and $p<0.10$.

\section{RESULTS}

\section{Sow and litter performance}

The effects of $\mathrm{MgSO}_{4}$ on sow and litter performance are shown in Table 2 . There were no differences $(p>0.05)$ in total number of piglets born, the number of piglets born alive, the number of stillborn piglets or the number of piglets per litter at weaning among the treatments. The litter birth body weight $(\mathrm{BW})$, the average piglet birth $\mathrm{BW}$, the average birth weight of all live-born piglets, the average piglet weaning BW and average daily gain (ADG) were not affected by dietary treatments $(p>0.05)$. The survival percentage and the litter weight at weaning were declined linearly $(\mathrm{p}<0.05)$ with increasing level of $\mathrm{MgSO}_{4}$. The ADFI of the sows during lactation, the sow BW loss from day 107 of gestation to weaning and the change in backfat during lactation were also not affected $(p>0.05)$ by adding $\mathrm{MgSO}_{4}$. However, the WEI was decreased linearly ( $\mathrm{p}=$ $0.05)$.

\section{Fecal moisture content}

As is shown in Table 3, fecal moisture content was increased (linear effect, $\mathrm{p}<0.05$ ) on day 7 of lactation and increased (linear and quadratic, $\mathrm{p}<0.05$ ) on day 20 of lactation as the level of $\mathrm{MgSO}_{4}$ increased. However, there 
Table 2. Effects of dietary supplementation of magnesium sulfate during late gestation and lactation on sow and litter performance ${ }^{1}$

\begin{tabular}{|c|c|c|c|c|c|c|c|}
\hline \multirow{2}{*}{ Item } & \multicolumn{4}{|c|}{ Magnesium sulfate $(\mathrm{mg} / \mathrm{kg})$} & \multirow{2}{*}{ SEM } & \multicolumn{2}{|c|}{ p-value } \\
\hline & 0 & 200 & 400 & 600 & & Linear & Quadratic \\
\hline Total piglets born & 11.92 & 11.83 & 12.00 & 12.17 & 0.24 & 0.178 & 0.232 \\
\hline Piglets born alive & 10.83 & 10.75 & 11.25 & 11.08 & 0.24 & 0.297 & 0.703 \\
\hline Stillborn piglets & 1.08 & 1.08 & 0.75 & 1.08 & 0.18 & 0.742 & 0.775 \\
\hline Piglets per litter at weaning & 9.42 & 9.17 & 9.25 & 8.83 & 0.19 & 0.120 & 0.432 \\
\hline Survival rate at weaning $(\%)$ & 87.11 & 85.23 & 83.25 & 82.29 & 1.73 & 0.010 & 0.067 \\
\hline Litter birth weight $(\mathrm{kg})$ & 17.63 & 17.95 & 17.40 & 17.25 & 0.34 & 0.284 & 0.538 \\
\hline Average piglet birth weight $(\mathrm{kg})$ & 1.49 & 1.54 & 1.44 & 1.44 & 0.03 & 0.326 & 0.674 \\
\hline Average birth weight of all live born piglets $(\mathrm{kg})$ & 1.54 & 1.56 & 1.45 & 1.49 & 0.03 & 0.324 & 0.728 \\
\hline Litter weight at weaning $(\mathrm{kg})$ & 50.46 & 49.67 & 48.82 & 46.30 & 1.31 & 0.046 & 0.115 \\
\hline Average piglet weaning weight $(\mathrm{kg})$ & 5.37 & 5.42 & 5.28 & 5.23 & 0.09 & 0.158 & 0.421 \\
\hline Day 0 to $21 \mathrm{ADG}(\mathrm{g} / \mathrm{d})$ & 182.8 & 178.3 & 180.7 & 177.1 & 4.0 & 0.252 & 0.656 \\
\hline Lactation ADFI (kg) & 4.66 & 4.62 & 4.33 & 4.38 & 0.08 & 0.124 & 0.457 \\
\hline Sow weight at day 107 of gestation $(\mathrm{kg})$ & 261.2 & 267.8 & 258.4 & 266.3 & 6.1 & 0.826 & 0.981 \\
\hline Sow weight at weaning day $21(\mathrm{~kg})$ & 221.5 & 228.0 & 217.8 & 220.8 & 5.6 & 0.630 & 0.899 \\
\hline Sow weight loss from day 107 of gestation to weaning $(\mathrm{kg})$ & 39.71 & 39.83 & 40.67 & 45.50 & 1.71 & 0.145 & 0.154 \\
\hline Sow backfat at post-farrowing day $0(\mathrm{~mm})$ & 21.33 & 22.08 & 21.58 & 21.50 & 0.70 & 0.996 & 0.669 \\
\hline Sow backfat at weaning day $21(\mathrm{~mm})$ & 17.67 & 18.42 & 17.58 & 17.58 & 0.64 & 0.648 & 0.770 \\
\hline Sow lactation backfat change (mm) & 3.67 & 3.67 & 4.00 & 3.92 & 0.18 & 0.183 & 0.560 \\
\hline WEI by 7 day post-weaning ${ }^{2}(\mathrm{~d})$ & 4.67 & 4.38 & 4.33 & 4.20 & 0.13 & 0.050 & 0.208 \\
\hline
\end{tabular}

SEM, standard error of mean; ADG, average daily gain; ADFI, average daily feed intake; WEI, weaning-to-estrus interval.

${ }^{1}$ Values are the means of 12 replicates. ${ }^{2} 9,8,9$, and 10 for treatments $1,2,3$, and 4 , respectively.

Table 3. Effects of dietary supplementation of magnesium sulfate during late gestation and lactation on the fecal moisture content of sows ${ }^{1}$

\begin{tabular}{|c|c|c|c|c|c|c|c|}
\hline \multirow{2}{*}{ Fecal moisture (\%) } & \multicolumn{4}{|c|}{ Magnesium sulfate $(\mathrm{mg} / \mathrm{kg})$} & \multirow{2}{*}{ SEM } & \multicolumn{2}{|c|}{ p-value } \\
\hline & 0 & 200 & 400 & 600 & & Linear & Quadratic \\
\hline Day 107 of gestation & 64.80 & 64.12 & 65.66 & 66.34 & 0.46 & 0.182 & 0.409 \\
\hline Day 7 of lactation & 65.12 & 65.94 & 66.53 & 68.06 & 0.39 & 0.021 & 0.122 \\
\hline Day 20 of lactation & 65.42 & 65.88 & 67.02 & 68.41 & 0.40 & 0.021 & 0.042 \\
\hline
\end{tabular}

SEM, standard error of mean. ${ }^{1}$ Values are the means of 8 replicates.

was no difference $(\mathrm{p}>0.05)$ in the fecal moisture content among the treatments on day 107 of gestation. Moreover, the number of the sows with severe constipation in the 0 , 200, 400, $600 \mathrm{mg} / \mathrm{kg} \mathrm{MgSO}$ treatments was 3, 2, 2, and 1 respectively.

\section{Colostrum and milk composition}

The composition of the sow colostrum and milk are shown in Table 4. No differences ( $p>0.05$ ) were observed in the total solid, fat or lactose levels of the milk among the treatments. However, linear trend in milk protein level $(\mathrm{p}=$ 0.095) was observed by increasing dietary $\mathrm{MgSO}_{4}$ level. There were no differences $(\mathrm{p}>0.05)$ in the lactose, protein or total solid levels of colostrum among the treatments. Fat content of the sow colostrum was decreased linearly ( $p<0.01$ ) with increasing level of $\mathrm{MgSO}_{4}$.

\section{Blood biochemistry parameters}

The blood biochemistry parameters are shown in Table
5. Plasma magnesium concentrations were increased on day 107 of gestation (linear and quadratic, $p<0.05$ ), day of farrowing and weaning (linear, $\mathrm{p}<0.05$ ). Plasma total protein tended to be linearly increased on day 107 of gestation $(\mathrm{p}=0.068)$ and day of weaning $(\mathrm{p}=0.057)$. Triglycerides level was declined with increasing level of $\mathrm{MgSO}_{4}$ (linear, $\mathrm{p}<0.05$ ) on day of farrowing.

\section{Plasma immunoglobulin levels of sows}

The IgG, IgA, and IgM levels in the plasma of sows are presented in Table 5. There were no differences $(p>0.05)$ in the $\operatorname{IgA}$ (day of farrowing and weaning) or $\operatorname{IgM}$ concentrations (day 107 of gestation, day of farrowing and weaning) among the treatments. Dietary supplementation of $\mathrm{MgSO}_{4}$ increased IgA level quadratically $(\mathrm{p}<0.05)$ on day 107 of gestation. The $\operatorname{IgG}$ level was increased linearly $(\mathrm{p}<0.05)$ as the level of $\mathrm{MgSO}_{4}$ increased on the day of farrowing. There were no linear and quadratic relationships (p>0.05) in plasma IgG level on day 107 of gestation and 
Table 4. Effects of dietary supplementation of magnesium sulfate during late gestation and lactation on the colostrum and milk composition in sows ${ }^{1}$

\begin{tabular}{|c|c|c|c|c|c|c|c|}
\hline \multirow{2}{*}{ Item } & \multicolumn{4}{|c|}{ Magnesium sulfate (mg/kg) } & \multirow{2}{*}{ SEM } & \multicolumn{2}{|c|}{ p-value } \\
\hline & 0 & 200 & 400 & 600 & & Linear & Quadratic \\
\hline \multicolumn{8}{|l|}{ Colostrum (\%) } \\
\hline Fat & 4.99 & 4.55 & 4.28 & 3.82 & 0.14 & 0.005 & 0.095 \\
\hline Lactose & 3.66 & 3.57 & 3.68 & 3.78 & 0.06 & 0.296 & 0.315 \\
\hline Protein & 16.48 & 18.51 & 19.79 & 17.31 & 0.46 & 0.663 & 0.269 \\
\hline Total solids & 26.68 & 27.82 & 28.55 & 26.43 & 0.45 & 0.997 & 0.317 \\
\hline \multicolumn{8}{|l|}{ Milk (\%) } \\
\hline Fat & 7.68 & 7.18 & 7.56 & 7.42 & 0.19 & 0.760 & 0.841 \\
\hline Lactose & 6.18 & 6.25 & 5.89 & 5.92 & 0.09 & 0.190 & 0.583 \\
\hline Protein & 4.86 & 4.80 & 5.25 & 5.37 & 0.15 & 0.095 & 0.384 \\
\hline Total solids & 20.79 & 20.27 & 20.81 & 20.65 & 0.22 & 0.938 & 0.908 \\
\hline
\end{tabular}

SEM, standard error of mean. ${ }^{1}$ Values are the means of 8 replicates.

day of weaning among the treatments.

\section{Immunoglobulin in colostrum and milk}

The IgG, IgA, and IgM levels in the colostrum and milk are shown in Table 6. The IgM concentrations in the colostrum and milk were not affected by adding $\mathrm{MgSO}_{4}$ $(\mathrm{p}>0.05)$. No linear and quadratic relationships $(\mathrm{p}>0.05)$ were observed in IgG levels of colostrum and milk among the treatments. A quadratic relationship $(\mathrm{p}<0.05)$ was observed in IgA level in the colostrum of sows with increasing level of $\mathrm{MgSO}_{4}$. The $\mathrm{IgA}$ concentration in the milk was increased linearly $(\mathrm{p}<0.05)$ with increasing level of $\mathrm{MgSO}_{4}$.

\section{DISCUSSION}

There are few studies on the effects of $\mathrm{MgSO}_{4}$ supplementation on sow and litter performance during late gestation and lactation. In our study, no significant differences were observed in the pregnancy parameters

Table 5. Effects of dietary supplementation of magnesium sulfate during late gestation and lactation on blood biochemistry parameters and plasma immunoglobulin levels in sows ${ }^{1}$

\begin{tabular}{|c|c|c|c|c|c|c|c|}
\hline \multirow{2}{*}{ Item } & \multicolumn{4}{|c|}{ Magnesium sulfate $(\mathrm{mg} / \mathrm{kg})$} & \multirow{2}{*}{ SEM } & \multicolumn{2}{|c|}{ p-value } \\
\hline & 0 & 200 & 400 & 600 & & Linear & Quadratic \\
\hline \multicolumn{8}{|l|}{ Day 107 of gestation } \\
\hline Magnesium (mmol/L) & 0.90 & 0.92 & 0.95 & 0.99 & 0.02 & 0.004 & 0.036 \\
\hline Total protein $(\mathrm{g} / \mathrm{L})$ & 80.98 & 80.85 & 86.10 & 87.66 & 0.91 & 0.068 & 0.334 \\
\hline Triglycerides (mmol/L) & 0.54 & 0.59 & 0.58 & 0.58 & 0.02 & 0.318 & 0.491 \\
\hline $\operatorname{IgG}(\mathrm{g} / \mathrm{L})$ & 5.13 & 5.29 & 7.12 & 5.88 & 0.21 & 0.417 & 0.678 \\
\hline $\operatorname{IgA}(\mathrm{g} / \mathrm{L})$ & 0.25 & 0.26 & 0.26 & 0.25 & $<0.01$ & 0.842 & $<0.001$ \\
\hline $\operatorname{IgM}(\mathrm{g} / \mathrm{L})$ & 0.30 & 0.36 & 0.35 & 0.36 & 0.01 & 0.201 & 0.388 \\
\hline \multicolumn{8}{|l|}{ Day of farrowing } \\
\hline Magnesium (mmol/L) & 0.78 & 0.79 & 0.83 & 0.88 & 0.01 & 0.024 & 0.103 \\
\hline Total protein $(\mathrm{g} / \mathrm{L})$ & 74.58 & 76.98 & 83.78 & 79.08 & 1.06 & 0.330 & 0.525 \\
\hline Triglycerides (mmol/L) & 0.24 & 0.23 & 0.20 & 0.19 & 0.01 & 0.026 & 0.224 \\
\hline $\operatorname{IgG}(\mathrm{g} / \mathrm{L})$ & 3.33 & 3.50 & 4.60 & 5.14 & 0.18 & 0.032 & 0.221 \\
\hline $\operatorname{IgA}(\mathrm{g} / \mathrm{L})$ & 0.21 & 0.21 & 0.25 & 0.24 & $<0.01$ & 0.223 & 0.628 \\
\hline $\operatorname{IgM}(\mathrm{g} / \mathrm{L})$ & 0.29 & 0.28 & 0.30 & 0.28 & $<0.01$ & 1.000 & 0.963 \\
\hline \multicolumn{8}{|l|}{ Day of weaning } \\
\hline Magnesium (mmol/L) & 0.88 & 0.92 & 0.97 & 0.97 & 0.01 & 0.038 & 0.182 \\
\hline Total protein $(\mathrm{g} / \mathrm{L})$ & 91.75 & 94.98 & 101.60 & 101.48 & 1.23 & 0.057 & 0.267 \\
\hline Triglycerides $(\mathrm{mmol} / \mathrm{L})$ & 0.22 & 0.23 & 0.30 & 0.22 & 0.02 & 0.775 & 0.674 \\
\hline $\operatorname{IgG}(\mathrm{g} / \mathrm{L})$ & 5.53 & 5.66 & 8.12 & 7.06 & 0.23 & 0.261 & 0.613 \\
\hline $\operatorname{IgA}(\mathrm{g} / \mathrm{L})$ & 0.20 & 0.25 & 0.23 & 0.24 & $<0.01$ & 0.393 & 0.584 \\
\hline $\operatorname{IgM}(\mathrm{g} / \mathrm{L})$ & 0.35 & 0.41 & 0.37 & 0.34 & 0.01 & 0.729 & 0.385 \\
\hline
\end{tabular}

SEM, standard error of mean; IgG, immunoglobulin G; IgA, immunoglobulin A; IgM, immunoglobulin M.

${ }^{1}$ Values are the means of 8 replicates. 
Table 6. Effects of dietary supplementation of magnesium sulfate during late gestation and lactation on the immunoglobulin levels in the colostrum and milk of sows ${ }^{1}$

\begin{tabular}{|c|c|c|c|c|c|c|c|}
\hline \multirow{2}{*}{ Item } & \multicolumn{4}{|c|}{ Magnesium sulfate $(\mathrm{mg} / \mathrm{kg})$} & \multirow{2}{*}{ SEM } & \multicolumn{2}{|c|}{ p-value } \\
\hline & 0 & 200 & 400 & 600 & & Linear & Quadratic \\
\hline \multicolumn{8}{|c|}{ Colostrum (g/L) } \\
\hline $\operatorname{IgG}$ & 45.03 & 47.76 & 52.38 & 50.88 & 0.98 & 0.127 & 0.315 \\
\hline $\operatorname{Ig} \mathrm{A}$ & 7.16 & 8.60 & 8.79 & 8.01 & 0.23 & 0.517 & 0.049 \\
\hline $\operatorname{IgM}$ & 3.22 & 3.66 & 3.92 & 3.49 & 0.12 & 0.530 & 0.224 \\
\hline \multicolumn{8}{|c|}{ Milk (g/L) } \\
\hline $\operatorname{IgG}$ & 0.74 & 0.73 & 0.76 & 0.79 & 0.01 & 0.122 & 0.195 \\
\hline $\operatorname{IgA}$ & 3.50 & 3.61 & 3.69 & 3.87 & 0.04 & 0.014 & 0.108 \\
\hline $\operatorname{IgM}$ & 1.53 & 1.53 & 1.56 & 1.51 & 0.02 & 0.812 & 0.689 \\
\hline
\end{tabular}

SEM, standard error of mean; IgG, immunoglobulin G; IgA, immunoglobulin A; IgM, immunoglobulin M.

${ }^{1}$ Values are the means of 8 replicates.

(litter size, litter weight) among the treatments, which may suggest that $\mathrm{MgSO}_{4}$ had no effects on the growth and development of fetuses during late gestation. Rattanatayarom et al. (2000) reported that pregnancy parameters were not adversely affected in sows supplemented with magnesium-L-aspartate hydrochloride daily at a dose of $13 \mathrm{mg} \mathrm{Mg}$ per $\mathrm{kg} \mathrm{BW}$ starting 0 to 4 days before mating. The present data indicated that the average piglet weaning weight and ADG during the suckling period were not affected by adding $\mathrm{MgSO}_{4}$, but the survival percentage and the litter weight at weaning were declined linearly with increasing level of $\mathrm{MgSO}_{4}$. On the contrary, Trawńska et al. (2013) reported that the feeding of pregnant sows with the addition of $\mathrm{MgCl}_{2} \cdot 6 \mathrm{H}_{2} \mathrm{O}(1 \mathrm{~g} / 100 \mathrm{~kg} \mathrm{BW} / \mathrm{d})$, which constituted $120 \mathrm{mg}$ of pure $\mathrm{Mg}$, decreased the mortality rate of the newborn piglets and increased the survival rate of piglets until 21 days of life and the litters BW.

An adequate feed intake is important for sow performance and reproduction (Koketsu et al., 1997). Feed intake was connected with BW loss, litter performance and backfat depth (Le Cozler et al., 1999; Eissen et al., 2003). In our study, supplementation of $\mathrm{MgSO}_{4}$ had no significant effects on the sow lactation ADFI, BW loss or backfat loss. Different with our results, Stockdale (2004) reported that adding 105 to $155 \mathrm{~g} \mathrm{MgSO}_{4}$ to the diet of cows during the last 3 weeks of gestation had a negative effect on intake before calving. Supplementation of $\mathrm{MgSO}_{4}$ at doses of $0.255,1.02$, and $2.04 \mathrm{~g} / \mathrm{kg}$ diet linearly reduced BW gain and feed intake in broiler chickens (Van der HoevenHangoor et al., 2013). Stockdale (2004) interpretated that supplementation of $\mathrm{MgSO}_{4}$ would seriously affect the palatability of the feed and reduce the feed intake. The possible reasons for the difference of these results are related to the animal species and $\mathrm{MgSO}_{4}$ level.

Constipation is a common state around farrowing (Tabeling et al., 2003; Oliviero et al., 2009). In clinical practice, osmotic laxatives are prescribed as the first-line agents for patients with severe constipation (Ikarashi et al., 2012). It is believed that osmotic laxatives such as magnesium oxide $(\mathrm{MgO})$ and $\mathrm{MgSO}_{4}$ induce diarrhea by increasing the osmotic pressure in the intestinal tract (Izzo et al., 1996). The laxative effect produced by $\mathrm{MgSO}_{4}$ is not simply a result of changes in osmotic pressure but is also associated with the increased expression of a water channel protein, aquaporin-3 $\left(\mathrm{AQP}_{3}\right)$, in the mucosal epithelial cells of the colon (Ikarashi et al., 2011a,b). The present study showed that supplementation of $\mathrm{MgSO}_{4}$ increased the fecal moisture content linearly during lactation. However, there was no difference in the fecal moisture content on day 107 of gestation among the treatments. This might be due to the higher concentration of the wheat bran in the diet of gestation sows compared to diet of lactation sows. Wheat bran contains adequate dietary fiber and can promote bowel movements to relieve constipation due to the waterretaining properties of insoluble fiber (Shen, 1998). Additionally, water consumption also has a great impact on fecal moisture content. Moreover, the number of the sows with severe constipation in the $\mathrm{MgSO}_{4}$ groups was less compared with the control group. In summary, the addition of $600 \mathrm{mg} / \mathrm{kg} \mathrm{MgSO}_{4}$ to the diet during late gestation and lactation may have the potential to prevent sow constipation to some extent. Similar finding on finishing pig constipation with the addition of $\mathrm{MgSO}_{4}$ to diets was reported by Tang (2000). According to Van der Hoeven-Hangoor et al. (2013), adding $\mathrm{Mg}\left(\mathrm{MgSO}_{4}, \mathrm{MgO}\right.$, and magnesium chloride $\left(\mathrm{MgCl}_{2}\right)$, each at 3 levels $(0.255,1.02$, and $2.04 \mathrm{~g} / \mathrm{kg}$ diet $\left.)\right)$ to the diet of broilers linearly increased the excreta moisture content, following the pattern $\mathrm{MgCl}_{2}>\mathrm{MgSO}_{4}=\mathrm{MgO}$, which has confirmed that $\mathrm{Mg}$ can prevent reabsorption of water from the digesta, and as a consequence, more moisture will be present in the excreta.

In the present study, the plasma $\mathrm{Mg}$ concentrations were significantly increased with the supplementation of $\mathrm{MgSO}_{4}$. This was in agreement with previous observations that supplementation with dietary $\mathrm{Mg}$ increased the serum $\mathrm{Mg}$ 
concentration in pigs (Rattanatayarom et al., 2000; Lahucky et al., 2004). The change of plasma total protein suggested that the supplementation of $\mathrm{MgSO}_{4}$ in sow diets could promote protein synthesis and strengthen protein deposition. The increase of plasma total protein was most likely caused by the fact that $\mathrm{Mg}$ participates in the metabolism of proteins due to its role in the action of many enzymes (Wolf and Cittadini, 2003).

The growth of suckling pigs depends on the availability and composition of colostrum and milk and the efficiency of their conversion into BW gain (Ariza-Nieto et al., 2011). A strong association exists between preweaning growth and the sow milk nutrient output (Noblet and Etienne, 1989). Reductions in the colostrum fat percentage were found in sows supplemented with $\mathrm{MgSO}_{4}$ during late gestation. In addition, the $\mathrm{MgSO}_{4}$ intake resulted in a higher milk protein content. However, Stockdale (2004) reported that $\mathrm{MgSO}_{4}$ had no effect on either milk yield or milk composition in cows. The fat in milk is a major source of energy, accounting for $55 \%$ to $60 \%$ of the total energy (Le Dividich and Seve, 2001). The high fat content of colostrum is essential to the survival and health of piglets (Jackson et al., 1995). Triglycerides are a primary component of the fat in mammary milk, and they mainly provide fatty acids (Boyd and Kensinger, 1998). The decrease in the colostrum fat content in this experiment may be linked to the lower plasma triglycerides in sows supplemented with $\mathrm{MgSO}_{4}$ on day of farrowing. According to Haenni et al. (1998), plasma $\mathrm{Mg}$ could significantly reduce plasma concentration of the fat. Moreover, supplementation of $\mathrm{Mg}$ in the diet improved lipid metabolism (Apple et al., 2000). The fat in milk is one of the important factors affecting piglet weight gain (Miller et al., 1994). This may be the reason for the decrease of survival percentage and the litter weight at weaning.

Several studies relating $\mathrm{Mg}$ to various aspects of the immune response have been published (Larvor, 1980; Galland, 1988; McCoy and Kenney, 1992). Magnesium is essential for the normal functioning of many components of the innate and adaptive immune defenses (Zimowska et al., 2002). The harmful effects of experimentally induced severe $\mathrm{Mg}$ deficiency on the immune system are well known, and experimental $\mathrm{Mg}$ deficiency has been shown to affect the humoral immune system (Alcock and Shils, 1974; Kubena et al., 1989; Windhauser et al., 1991). Regarding the effects of dietary $\mathrm{MgSO}_{4}$ on immunoglobulin levels, dietary supplementation of $\mathrm{MgSO}_{4}$ during gestation and lactation resulted in the linear increase of plasma $\operatorname{IgG}$ concentrations in sows on the day of farrowing, but no linear and quadratic relationships were found in the colostrum and milk. We also found that the treaments supplemented with $\mathrm{MgSO}_{4}$ resulted in the increase of $\mathrm{IgA}$ concentrations in the colostrum and milk. The data suggested that a higher $\mathrm{MgSO}_{4}$ intake induced elevated $\mathrm{IgG}$ production in the blood of the sows, which could improve the host defense against invading pathogens. According to Galland (1988), $\mathrm{Mg}$ is involved in the synthesis of immunoglobulins and the activation of complement, and it impacts the function of phagocytes and regulates the maturation and function of $\mathrm{T}$ lymphocytes. Maternal immunity is very important to maintain the health status of pigs and their production levels (Le Dividich, 2006). The survival of neonatal pigs is totally dependent on maternal immunity via the colostrum and milk due to the epitheliochorial placenta (Kim, 1975). The colostrum provides newborn piglets with maternal serum antibodies, the majority of which are IgG (Bourne and Curtis, 1973). Colostral IgG is translocated from the blood to the mammary gland (Salmon et al., 2009). This process nearly stops just after parturition, resulting in a sharp decrease in the colostral $\mathrm{IgG}$ concentration when the colostrum becomes milk (Klobasa et al., 1987). As lactation proceeds, IgG concentrations decrease and IgA becomes the major immunoglobulin in sow milk (Gaskins, 1998). Immunoglobulin $G$ is predominantly involved in the secondary antibody response, whereas IgA plays a critical role in mucosal immunity (Ariza-Nieto et al., 2011). In our study, the $\mathrm{MgSO}_{4}$ treatments improved the milk IgA levels. In pigs, nearly $100 \%$ of milk IgA originated from IgA synthesized locally into the mammary gland (Bourne and Curtis, 1973). These results showed that $\mathrm{MgSO}_{4}$ could stimulate the mammary tissue to synthesize $\operatorname{IgA}$. The milk antibody (especially $\operatorname{IgA}$ ) cannot be absorbed into the blood, but it protects against local pathogens, commensal bacteria and food antigens in the topical digestive tract (Brandtzaeg, 2010). Our study demonstrated that supplementation with $\mathrm{MgSO}_{4}$ enhanced the IgA level in the colostrum and milk, which may support the better protection of piglets. However, the increases of immunoglobulin levels in the colostrum and milk did not result in gains by the piglets while suckling.

\section{CONCLUSION}

The results suggest that supplementation with 200, 400, or $600 \mathrm{mg} / \mathrm{kg}$ of $\mathrm{MgSO}_{4}$ decreased the survival percentage and the litter weight at weaning linearly and did not affect other parameters of the sow or litter performance. The addition of $\mathrm{MgSO}_{4}$ to the diet during late gestation and lactation increased the fecal moisture content linearly during lactation. Supplementation with $\mathrm{MgSO}_{4}$ linearly increased the concentrations of plasma $\mathrm{Mg}$ and total protein. Supplementation with $\mathrm{MgSO}_{4}$ increased the plasma IgG level of sows on the day of farrowing and $\operatorname{IgA}$ level in the milk. Additionally, an increase in the dietary $\mathrm{MgSO}_{4}$ level during late gestation and lactation resulted in a linear decrease of colostrum fat and an increase of milk protein. 
We conclude that supplementation with $\mathrm{MgSO}_{4}$ during late gestation and lactation may have the potential to prevent sow constipation, but result in some negative effects.

\section{ACKNOWLEDGMENTS}

This work was supported by China Agriculture Research System (CARS-36) and the Key Program of Heilongjiang Province (No. WB13B101). We would like to thank Dawan Pig Breeding Farm (Mudanjiang, China) for their assistance.

\section{REFERENCES}

Alcock, N. W. and M. E. Shils. 1974. Serum immunoglobulin G in the magnesium-depleted rat. Proc. Soc. Exp. Biol. Med. 145: 855-858.

AOAC. 2006. Official Methods of Analysis. 18th edn. Association of Official Analytical Chemists, Arlington, VA, USA.

Apple, J. K., C. V. Maxwell, B. DeRodas, H. B. Watson, and Z. B. Johnson. 2000. Effect of magnesium mica on performance and carcass quality of growing-finishing swine. J. Anim. Sci. 78: 2135-2143.

Apple, J. K., E. B. Kegley, C. V. Maxwell, L. K. Rakes, D. Galloway, and T. J. Wistuba. 2005. Effects of dietary magnesium and short-duration transportation on stress response, postmortem muscle metabolism, and meat quality of finishing swine. J. Anim. Sci. 83:1633-1645.

Ariza-Nieto, C., M. Bandrick, S. K. Baidoo, L. Anil, T. W. Molitor, and M. R. Hathaway. 2011. Effect of dietary supplementation of oregano essential oils to sows on colostrum and milk composition, growth pattern and immune status of suckling pigs. J. Anim. Sci. 89:1079-1089.

Bourne, F. J. and J. Curtis. 1973. The transfer of immunoglobulins $\mathrm{IgG}, \mathrm{IgA}$ and $\mathrm{IgM}$ from serum to colostrum and milk in the sow. Immunology. 24:157-162.

Boyd, R. D. and R. S. Kensinger. 1998. Metabolic precursors for milk synthesis. In: Lactating Sow, 1st Ed. (Eds. M. W. A. Verstegen, P. J. Morgan, and J. W. Schrama). Wageningen Press, Wageningen, Netherlands. pp.71-95.

Brandtzaeg, P. 2010. The mucosal immune system and its integration with the mammary glands. J. Pediatr. 156:S8-S15.

Cowart, R. P. 2007. Parturition and dystocia in swine. In: Large Animal Theriogenology (Eds. R. S. Youngquist and W. R. Threlfall). Saunders, St. Louis, MI, USA. pp. 778-784.

D'souza, D. N., R. D. Warner, B. J. Leury, and F. R. Dunshea. 1998. The effect of dietary magnesium aspartate supplementation on pork quality. J. Anim. Sci. 76:104-109.

Eissen, J. J., E. J. Apel doorn, E. Kanis, M. W. A. Verstegen, and K. H. de Greef. 2003. The importance of a high feed intake during lactation of primiparous sows nursing large litters. J. Anim. Sci. 81:594-603.

Galland, L. 1988. Magnesium and immune function: An overview. Magnesium 7:290-299.

Gaskins, H. R. 1998. Immunological development and mucosal defence in the pig intestine. Pages 81-10 In: Progress in Pig Science (Eds. J. Wiseman, M. A. Varley, and J. P. Chadwick).
Nottingham University Press, Nottingham, UK. pp. 81-10.

Guerrera, M. P., S. L. Volpe, and J. J. Mao. 2009. Therapeutic uses of magnesium. Am. Fam. Physician. 80:157-162.

Haenni, A., M. Ohrvall, and H. Lithell. 1998. Atherogenic lipid fractions are related to ionized magnesium status. Am. J. Clin. Nutr. 67:202-207.

Hermansson, I., S. Einarsson, K. Larsson, and L. Backstrom. 1978. On the agalactia postpartum in the sow. A clinical study. Nord. Vet. Med. 30: 465-473.

Ikarashi, N., A. Mimura, R. Kon, T. Iizasa, M. Omodaka, C. Nagoya, M. Ishii, T. Toda, W. Ochiai, and K. Sugiyama. 2012. The concomitant use of an osmotic laxative, magnesium sulphate, and a stimulant laxative, bisacodyl, does not enhance the laxative effect. Eur. J. Pharm. Sci. 45:73-78.

Ikarashi, N., T. Mochiduki, A. Takasaki, T. Ushiki, K. Baba, M. Ishii, T. Kudo, K. Ito, T. Toda, W. Ochiai, and K. Sugiyama. 2011a. A mechanism by which the osmotic laxative magnesium sulphate increases the intestinal aquaporin 3 expression in HT-29 cells. Life Sci. 88: 194-200.

Ikarashi, N., T. Ushiki, T. Mochizuki, T. Toda, T. Kudo, K. Baba, M. Ishii, K. Ito, W. Ochiai, and K. Sugiyama. 2011b. Effects of magnesium sulphate administration on aquaporin 3 in rat gastrointestinal tract. Biol. Pharm. Bull. 34:238-242.

Izzo, A. A., T. S. Gaginella, and F. Capasso. 1996. The osmotic and intrinsic mechanisms of the pharmacological laxative action of oral high doses of magnesium sulphate. Importance of the release of digestive polypeptides and nitric oxide. Magnes. Res. 9:133-138.

Jackson, J. R., W. L. Hurley, R. A. Easter, A. H. Jensen, and J. Odle. 1995. Effects of induced or delayed parturition and supplemental dietary fat on colostrum and milk composition in sows. J. Anim. Sci. 73:1906-1913.

Kim, Y. B. 1975. Developmental immunity in the piglet. Birth Defects Orig. Artic. Ser. 11:549-557.

Klobasa, F., E. Werhahn, and J. E. Butler. 1987. Composition of sow milk during lactation. J. Anim. Sci. 64:1458-1466.

Koketsu, Y., G. D. Dial, J. E. Pettigrew, and V. L. King. 1997. Influence of feed intake during individual weeks of lactation on reproductive performance of sows on commercial farms. Livest. Prod. Sci. 49:217-225.

Kubena, K. S., D. T. Cohill, and D. N. McMurray. 1989. Effect of varying levels of magnesium during gestation and lactation on humoral immune response and tissue minerals in rats. Ann. Nutr. Metab. 33:7-14.

Lahucky, R., K. Nuernberg, U. Kuechenmeister, I. Bahelka, J. Mojto, and G. Nuernberg. 2004. The effect of dietary magnesium oxide supplementation on fatty acid composition, antioxidative capacity and meat quality of heterozygous and normal malignant hyperthermia pigs. Arch. Tierz., Dummerstorf. 47:183-191.

Larvor, P. 1980. Magnesium, humoral immunity, and allergy. In: Magnesium in Health and Disease Proceedings of the 2nd International Symposium on Magnesium (Eds. M. Cantin and M. S. Seelig). SP Medical and Scientific Books, New York, USA. pp. 201-224.

Le Cozler, Y., E. Ringmar-Cederberg, L. Rydhmer, N. Lundeheim, J. Y. Dourmad, and M. Neil. 1999. Effect of feedings level during rearing and mating strategy on performance of Swedish Yorkshire sows: 2. Reproductive performance, food intake, 
backfat changes and culling rate during the first two parities. Anim. Sci. 68:365-377.

Le Dividich, J. 2006. The issue of colostrum in piglet survival: energy and immunity. In: Biotechnology in the Feed Industry: Proceedings of Alltech's 22 Annual Symposium (Eds. T. P. Lyons and K. A. Jacques). Nottingham Press University, Nottingham, UK. pp. 89-102.

Le Dividich, J. and B. Seve. 2001. Energy requirement of the young pig. In: The Weaner Pig (Eds. M. A. Varley and J. Wiseman). CABI Publishing, Wallingford, UK. pp. 17-44.

Lee, S. and W. M. Britton. 1980. Magnesium toxicity: Effect on phosphorus utilization by broiler chicks. Poult. Sci. 59:19891994.

Liu, Z. K. and B. R. Luo. 2010. Investigation of sow reproductive condition in part scale pig farms in seven provinces of China. Swine. Prod. 5:65-68.

Maguire, M. E. and J. A. Cowan. 2002. Magnesium chemistry and biochemistry. Biometals. 15:203-210.

McCoy, H. and M. A. Kenney. 1992. Magnesium and immune function: recent findings. Magnes. Res. 5:281-293.

Miller, M. B., T. G. Hartsock, B. Erez, L. Douglass, and B. AlstonMills. 1994. Effect of dietary calcium concentrations during gestation and lactation in the sow on milk composition and litter growth. J. Anim. Sci. 72:1315-1319.

National Research Council. 1998. Nutrient Requirements of Swine. 10th Ed. National Academy Press, Washington, DC, USA.

Noblet, J. and M. Etienne. 1989. Estimation of sow milk nutrient output. J. Anim. Sci. 67:3352-3359.

Oliviero, C., T. Kokkonen, M. Heinonen, S. Sankari, and O. Peltoniemi. 2009. Feeding sows with high fibre diet around farrowing and early lactation: impact on intestinal activity, energy balance related parameters and litter performance. Res. Vet. Sci. 86:314-319.

Rattanatayarom, W., K. Korteerakul, H. G. Classen, and L. Spatling. 2000. Effects of magnesium-L-aspartate hydrochloride supplements in pregnant sows. Magnes. B. 22:39-44.

Salmon, H., M. Berri, V. Gerdts, and F. Meurens. 2009. Humoral and cellular factors of maternal immunity in swine. Dev. Comp. Immunol. 33:384-393.

Shen, Y. M. 1998. Characteristics and application of dietary fiber. Cereals and Oils 4:2-4
Shi, M. K. 2010. Reasons and prevention measures for sow constipation in intensive farms. Chinese J. Anim. Quar. 27:5960.

Siener, R., A. Jahnen, and A. Hesse. 2011. Bioavailability of magnesium from different pharmaceutical formulations. Urol. Res. 39:123-127.

Smith, B. B. 1985. Pathogenesis and therapeutic management of lactation failure in periparturient sows. Compend. Contin. Educ. Prac. Vet. 7: S523-S532.

Stockdale, C. R. 2004. Effects of feeding magnesium sulfate to dry pregnant dairy cows with different body condition scores on intake in late gestation, periparturient blood calcium concentrations and production in early lactation. Anim. Prod. Sci. 44:539-546.

Tabeling, R., S. Schwier, and J. Kamphues. 2003. Effects of different feeding and housing conditions on dry matter content and consistency of faeces in sows. J. Anim. Physiol. Anim. Nutr. 87:116-121.

Tang, D. H. 2000. Effect of feeding magnesium sulfate to fattening pigs on constipation. Lives. Poult. Ind. 6:24-25.

Trawńska, B., A. Polonis, J. Lechowski, L. Tymczyna, R. Borowski, and K. Gizińska. 2013. Effect of the addition of magnesium salt to a feed mixture on intestinal microflora, health, and production of sows. Bull. Vet. Inst. Pulawy 57:6972.

Van der Hoeven-Hangoor, E., I. B. Van de Linde, N. D. Paton, M. W. A.Verstegen, and W. H. Hendriks. 2013. Effect of different magnesium sources on digesta and excreta moisture content and production performance in broiler chickens. Poult. Sci. 92: 382-391.

Windhauser, M. M., L. C. Kappel, and M. Hegsted. 1991. The humoral immune response in marginally and severely magnesium deficient rats. J. Nutr. Biochem. 2:541-546.

Wolf, F. I. and A. Cittadini. 2003. Chemistry and biochemistry of magnesium. Mol. Aspects Med. 24:3-9.

Yang, Y., M. Y. Gao, W. Nie, J. M. Yuan, B. K. Zhang, Z. Wang, and $\mathrm{Z}$. L. Wu. 2012. Dietary magnesium sulfate supplementation protects heat stress-induced oxidative damage by restoring the activities of anti-oxidative enzymes in broilers Biol. Trace Elem. Res. 146:53-58.

Zimowska, W., J. P. Girardeau, J. Kuryszko, D. Bayle, Y. Rayssiguier, and A. Mazur. 2002. Morphological and immune response alterations in the intestinal mucosa of the mouse after short periods on a low-magnesium diet. Br. J. Nutr. 88:515-522. 